\title{
Dams and Displacement in Turkey and Pakistan
}

\author{
Abdul Hadi \\ Assistant Professor. Harran University, Faculty of Arts and Sciences, \\ Department of Sociology, "Şanlıurfa" Turkey. \\ Email: ahadi@harran.edu.tr \& hadijarwar@gmail.com
}

\begin{abstract}
The development policy makers in both Turkey and Pakistan believe that the construction of dams would bring development and prosperity in their countries. Believing in this development model, so far many dams have been constructed and others are either under the construction or in planning process in both countries. The evidences are steadily mounting and reveal that the benefits of dams have been over exaggerated and their social and ecological costs were grossly underestimated. Construction of dams resulted in the displacement of thousands of people in both countries. With the help of existing literature and studies, this study has focused on the living conditions of displacees after the construction of dams in both countries. This study has found that in the case of Turkey due to inequitable land distribution major benefits of dams mostly beneficiaries of dam projects are people who are already well-off and but the people who were displaced due to dams and also were landless are living worse life compared with their previous living conditions. In Pakistan, there were resettlements plans for reservoir-induced displacees but not for deltaic people who were the most affectees. The reduction in fresh water flow and the encroachment of sea have brought destruction to both delta and deltaic people. In the absence of any resettlement plan and compensation, these people are forced to live in the slum areas of big cities and facing miserable poverty and psychological problems.
\end{abstract}

Keywords: Dams, Displacement, Environmental Justice, Turkey, Pakistan

\section{Introduction}

There is implicit or explicit assumption behind all development policies in the third world countries that in order to achieve 'the good life' one must follow the path of North that is industrialization, technological progress and capital accumulation. On the other side, both trade liberalisation and economic globalisation have allowed firms greater discretion in deciding both where to locate their production activities and in what places to dump the wastes which arise from these. Dam-building industry in the First World, Being in trouble and out of work, is exported to the Third World in the name of Development Aid.Today, most dam construction has shifted from the developed to the developing world such as China and India are few examples of them who are implementing large dam construction programmes (McCully,2001,pp.xv).

Dams have been symbolized as development and progress and human's conquest over nature. Water resource development has been dominated by engineers, most of whom have regarded the construction of a dam as a technical matter that non-engineers cannot understand. The bureaucratic structures, ideology of progress and profit has kept the construction of dams continue since many decades ever questioning the negative impacts of dams or evaluating whether the promises of water, power, food, and prosperity for all have actually been realized.

The evidence is steadily mounting and reveals that dams have not fulfilled the promises made for them. Their benefits have been over exaggerated and their social and ecological costs were grossly underestimated. The World Commission on Dams (WCD) and other studies found that dams have on average fail to reach their promised targets. Instead Dams have had massive negative impacts on nature and society. Dams cause livelihood insecurity for the 'ecosystem people'. Indigenous people, tribal and peasant communities have been particularly very badly affected. The WCD report (2000) concluded in its executive summary that the "pervasive and systematic failure to assess the range of potential negative impacts and implement adequate mitigation, resettlement and development programs for the displaced and the failure to account for the consequences of large dams for downstream livelihoods have led to the impoverishment and suffering of millions". 
There is a large literature that argues that the beneficiaries of dam projects tend to be people who are already well-off. However, it is argued that those who pay the greatest cost of large dam construction tend to be poor, marginalized and vulnerable members of society. In almost all cases, the people affected by construction of dams are rarely included in decisions about whether or not to build a dam (Wood, 2007) As for as benefits of dams concerned, factories and city residents benefit from power generated or water stored by dams. Large agricultural companies benefit from cheap water for irrigation. Construction and engineering companies benefit too. They receive millions of dollars for designing and building dams. Governments can benefit from taxes collected during construction or operation of a dam (IRN, 2006).

The development policy makers in both Turkey and Pakistan believe that the construction of dams will bring development and prosperity in their countries. Believing in this development model, so far many dams have been constructed and others are either under the construction or in planning process in both countries. In Turkey, The GAP (Güney Anadolu Projesi) is designed to harness the waters of Tigris and Euphrates rivers with the construction of 22 dams and 19 Hydroelectric Power Plants (HEPP). According to Action plan (2014) GAP is being implemented as an integrated regional development project based on sustainable human development focusing on competitive power and economic and social integration. This project is planned to develop the socio-economic condition and cultural aspects of Turkey including human-focused, innovative and sustainable projects and programs that are intended to reduce income disparities, gives priority to groups and area that are disadvantaged. Aygüney (2002) argues that "The objectives of GAP and the activities carried out within the project stand as applications of the 'catching-up' theory at a smaller scale, giving the western regions of Turkey a higher status on the path to development while defining Southeast Anatolia as 'underdeveloped'. Similarly, The construction of dams in Pakistan, in particular Tarbela and Mangla were built by on the belief that dams will bring development and prosperity in Pakistan by irrigating the lands and generating electricity. The development policy makers in Pakistan even ignored the concerns of independent research scholars and people who claimed that the construction of dams would bring disaster to the people and Indus Delta.

Diversion of water resources by large dams and reservoirs in the River Basins have had major impacts on the rivers morphology, their ecosystem and lands, and on the health and welfare of population which is dependent on the their resource base for their survival. mega projects bring benefits for the creamy layer of the population. But on the other hand all such projects create a threat to the livelihood of the ecosystem people subsisting on land, water and the forest in a sustainable manner (Meher, 2011). Dams displace huge populations of people, leaving them homeless and destitute (Roy, 1999). These results are similar to the results of wars and conflicts in the rest of the world (Snoubar \& Duman, 2016., Snoubar, 2017). Poorest sections of societies such as rural farmers and indigenous or tribal peoples have paid the price of these dams. They are the ones who have suffered most from dams (McCully, 2001; IRN, 2006).

General consensus has been found among development agents that development induced displacement causes serious disruption and losses for the people and communities (Dwivedi 1999; WCD, 2000). The key issues are those of socioeconomic impoverishment, human rights, citizen entitlements and the relationships between them. Adverse effects of displacement typically include the loss of livelihoods, loss of land rights and housing and loss of social networks. It is also recognized that disadvantaged people and communities bear the disproportionate burden of these negative effects.

Taken together, the human rights issues boil down to the question of who benefits and who pays in large dam projects. There is a large literature that argues that the beneficiaries of dam projects tend to be people who are already well-off. However, it is argued that those who pay the greatest cost of large dam construction tend to be poor, marginalized and vulnerable members of society. This raises the question of environmental justices. This study will focus on the impacts of dams on people and their living conditions after displacement by using the by analyzing the existing documents and research papers.

\section{Environmental Justice Perspective}

The construction of dams raises serious environmental justice concerns, with economic benefits for some people in some places and environmental costs for other people at other times and in other places. At the heart of environmental justice agenda are the question that who pay the cost and who get benefits from development projects and economic growth. Many environmental justice struggles in the global South have been spearheaded by local and indigenous communities in opposition to development projects that threaten their lands, livelihoods, and natural resources (Guha, 2000; Gonzalez, 2012). Edwards (1995) states that environmental justice discovers, neither environmental burden nor environmental good are equally distributed throughout our society. Environmental Injustice occurs when some communities disproportionately 
bear environmental burdens, or have not equal access to environmental benefits, or have less opportunity in environmental decision-making process (Shrader-Frechette, 2002). Hence they experience distributional injustice and procedural unfairness as alleged by environmental justice advocates. The principles of Environmental Justice (EJ) outline three major concepts of EJ: no community should bear a disproportionate burden of environmental hazards, all communities should have access to environmental benefits, and decision-making processes need to be transparent and include community voices (Vanderwarker, 2012). Environmental justice advocates alleged "distributive injustice in the form of disproportionate exposure to environmental hazards; procedural unfairness in environmental decision-making; corrective injustice due to inadequate environmental enforcement; and social injustice because environmental degradation cannot be separated from other problems plaguing low income communities and communities of color (such as unemployment and underfunded schools)" (Kuehn, 2000). The issue of environmental justice will be analysed by seeing the condition of people who were displaced in both countries.

\section{Displacees of Dams in Turkey and Pakistan}

Displacement of people from the areas where they live, grow crops, fish and raise livestock make most people poorer. They face problems getting enough food to eat and money to support their families (IRN, 2006, pp.10)Between 40 and 80 million people have been forcedly displaced in wake of dams. Most of these people are living under the poverty; their cultures and communities have been ruined (IRN, 2006, pp.7)The calculation of worldwide dam-induced displacement, according to the figures of WCD is 40-80 million.( McCully,2001,pp.xxxi). The WCD reprted that $75 \%$ of Indians ousted by dam have not been 'rehabilitated' and are impoverished (Sims, 2001; McCully,2001)

Güney Anadolou Projesi (GAP) in Turkey stands as a "regional development project". However, it is not providing sustainable future for the soil and local people. The adverse effects of the project are locally concentrated but the remarkable gains are being achieved at the national level (Aygüney2002). The GAP project, despite aiming to achieve "sustainable human development", is not sustainable human development. Forced displacement of the people and inappropriate resettlements has caused the problem. So far, more than 350,000 people in Southeast Anatolia have been displaced by the GAP project. Eviction on this scale causes deep economic and cultural disruption for the individuals affected, as well as to the social fabric of local communities.

Displacees of the Ataturk dam, the part of GAP, in the 1990s, where the majority of people who were displaced were not resettled properly and are still living in temporary resettlements (Akyürek, 2005). Compensation is usually tied in this region to the property of the land or houses. Since most land in this region is concentrated in the hands of tiny minority of big landholders, many landless families were totally deprived of compensation.Nearly 30,000 people were affected with the construction of Birecik dam, of whom just 6,500 people were resettled. In order to investigate the perception of people regarding resettlements, Miyata (2004) conducted a research and found that one third of villagers were unhappy with the resettlement and perceived the resettlement condition worse. People used to have multiple jobs now more than 70 percent people have to rely on either one job or no job. Likewise Kurt (2013) conducted a research on resettlers' livelihoods after the resettlement in Halfeti area, Turkey. He argues that the building of the dam has had different impacts on different households. Whereas better-off households are more resilient to vulnerability, poorer households were observed as being more vulnerable to poverty, because they have few assets and lack the capability to combine these assets to make a sustainable living. Therefore, these studies reveals that the constructions of dam my benefit the people as a whole in country, but the landless displacees are living worse life compared with their previous living conditions. The inequitable land distribution in this region deprived landless people to get compensation as compensation is mainly tied to land and houses. Thus, These people are facing environmental injustice.

The inundation of land and alteration of riverine ecosystems disrupt local economies, it effectively displaces people - in a wider sense - from access to a series of natural resource and environmental inputs into their livelihoods. This form of livelihood displacement deprives people of their means of production and dislocates them from their existing socio-cultural milieu. In Pakistan, The reduction in fresh water flow and the encroachment of sea have brought destruction to both delta and deltaic people. Hundreds of villages have been wiped off the map; thousands of people were forced to out-migrate, their homes, lands, and other properties have been lost.

The degeneration of the natural resources has deteriorated human settlements compelling plenty of people of the coast to migrate to other areas in search of water and food. Fisher folks (Mohanas) communities mostly live around the rivers, the lakes, and the coastal areas. Due to water shortage, the lives of these folks have been enormously disturbed, which forced 
them migrate out in search of livilihood. It is not only devastating for these folks to adjust to a new way of life or location but also a great loss to the cultural diversity of Sindh. In the typical Pakistani society, where women are often socially secluded, social assets and relations take decades to frame. With displacement, women lose their social relations and cannot regain them in their lifetime. The socio-economic study conducted by World Bank (2005) found that there is significant outmigration, especially, from the coastal areas of Thatta as a result of the shortage of drinking water and disruption of livelihoods. Hundreds of villages in the Badin and Thatta districts have been deserted. The seawater intrusion has completely uprooted many villages of the area. It is estimated that 90,000 people have become displaced and 120 villages uprooted. A large number of villages in the proximity of the sea still face threats of inundation (DDMA, 2008). In a Survey conducted by the government of Sindh indicated that over 486,000 hectares land were eroded or lost to the sea-water within Thatta and Badin districts, dislocating a quarter million people. The seawater has destroyed at least one-third of the land (SAP, 2001). It must be kept in mind that development policy makers that there is neither a resettlement policies nor compensation for the people who were displaced in delatic region of Sindh. The great majority of those displaced deltaic people in Pakistan are living in the slums areas. They often suffer emotional and physical problems. Alcoholism, depression, domestic violence, disease and even suicide often increase after they are displaced.

However government of Pakistan have some resettlement policies for the victims who displaced due to the reservoirs of dams but these policies are not satisfactory. At the Mangla Dam, about 110,000 people were displaced. The cultural and religious landmarks and the historic town of Mirpur were sacrificed despite people's resistance. About 96,000 land owners were displaced from the Tarbela Project. The total number of people affected was far larger than this figure as landless were not compensated. Some people have not yet been settled and there are 412 pending cases from the 1970 s still being contested (Gazdar, 1990)

The consturction of dams in Pakistan has forcedly displaced people in the reservoir areas. Though there were resettlments plans but not adequate enough to address the grievances of people as it is noted that many of many of the people were not resettled even after two or three decades of construction. In the case of Pakistan, Indus deltaic communities are very unfortunate that they were not neither thought of for resettlement plan nor of compensation. As a result there were forced to live in slum areas and facing environmental injustice befallen on them due to inappropriate development policies.

\section{Conclusion}

The development policy makers in both Turkey and Pakistan believe that the construction of dams would bring development and prosperity in their countries. Believing in this development model, so far many dams have been constructed and others are either under the construction or in planning process in both countries. However, the evidence is steadily mounting and reveals that dams have not fulfilled the promises made for them. Their benefits have been over exaggerated and their social and ecological costs were grossly underestimated. Studies argue that in Turkey mostly beneficiaries of dam projects are people who are already well-off due to inequitable land distribution in this region. The inequitable land distribution in this region deprived landless people to get compensation as compensation is mainly tied to land and houses. Therefore, it can be concluded that the constructions of dam my benefit the people as a whole in country, but the people who were displaced due to dams and were also landless are living worse life compared with their previous living conditions.

The construction of dams in Pakistan has forcedly displaced people in the reservoir areas. Though there were resettlements plans but not adequate enough to address the grievances of people as it is noted that many of many of the people were not resettled even after two or three decades of construction.

In Pakistan, the more ignored impactees and displacees of dams are deltaic people. The reduction in fresh water flow and the encroachment of sea have brought destruction to both delta and deltaic people. Hundreds of villages have been wiped off the map; thousands of people were forced to out-migrate, their homes, lands, and other properties have been lost. It is not only devastating for these folks to adjust to a new way of life or location but also a great loss to the cultural diversity of Sindh. In the typical Pakistani society, where women are often socially secluded, social assets and relations take decades to frame. With displacement, women lose their social relations and cannot regain them in their lifetime. The development policy makers do not regard deltaic people of Indus delta as affectees. Therefore, there is neither a resettlement plans nor compensation in any form for them. As a result, they are forced to live in slum areas of big cities facing environmental injustice befallen on them due to inappropriate development policies. They often suffer emotional and physical problems. Alcoholism, depression, domestic violence, disease and even suicide often increase after they are displaced. 
It is the need of time to take initiative for the better of affectees so that their lives can be better off. It is also recommended that before planning or implementing these types of development projects, the most would-be affectees should be consulted and informed and their perceptions and concerns should be properly addressed.

\section{References}

[1] Akyürek, G. (2005). Impact of ataturk dam on social and environmental aspects of the Southeastern Anatolian Project (Master's Thesis). Middle East Technical University (METU), Turkey.

[2] Aygüney, N. (2002). A burden of 'development' in southeastern turkey: salinization and socio-cultural disruption. (Master's Thesis). Lund University, Sweden.

[3] DDMA,. (2008). District Disaster Management Authority. Disaster Risk Management Plan, District Thatta, Government of Sindh.

[4] Dwivedi, R. (1999). Displacement, risks and resistance: local perceptions and actions in the sardar sarovar. Development and Change 30 (1): 43-78.

[5] Edwards, B. (1995) With liberty and environmental justice for all: the emergence and challenge of grassroots. In Taylor Environmentalism in the United States.

[6] Gazdar N.M., (1990). An assessment of the Kalabagh Dam project on the River Indus Pakistan-The sabzeBagh 'promising a rose garden but delivering dust', Environmental Management Society.

[7] Gonzalez, C.G. (2013). Environmental justice and international environmental law. In S. Alam, J.H. Bhuiyan, T. Chowdhury, and E.J. Techera (Ed.) Routledge Handbook of International Enviornmental Law, Chapter 5:77-97.

[8] Government of Sindh,. (2004). Board of Revenue, Hyderabad.

[9] Government of Sindh. (2001). Status of Education Survey Data Functional Schools, Govt. of Sindh.

[10] Guha, R. (2000). Environmentalism: A Global History. New York: Longman.

[11] IRN, .(2006). Dams, rivers and rights: An Action Guide for Communities Affected by Dams.

[12] Kuehn, R.R. (2000). A taxonomy of environmental justice. Environmental Law Reporter Vol. 30, p. 10681-10703.

[13] Kurt, C. (2013). The impact of the southeast anatolia project (gap) on displaced families: household livelihoods and gender relations (Doctoral Thesis). The Newcastle University, UK.

[14] McCully, P. (2001) Silenced rivers: the ecology and politics of large dams: Enlarged and Updated edition, Zed Books Ltd.

[15] Meher, R. (2011). Big dam, big failures: a study of the canal irrigation system and the deprived tail-end farmers in the hirakud command Area of Orissa, India. Journal of Asian and African Studies 46(4): 422-438.

[16] Memon, A., (2005) Devastation of the indus river delta. Environmental and Water Resources Institute, Anchorage, Alaska.

[17] Miyata, S. (2004). Living conditions in resettled households of the Birecik Dam area in the south east Turkey: Initial findings from a household survey.

[18] SAP. (2001). Water crisis in Pakistan: news clippings, reports, articles. A South Asia Partnership Report.

[19] Shrader-Frechette, K. (2002). Environmental justice: Creating Equality, Reclaiming Democracy. Oxford university press.

[20] Sims. H., (2001). Moved, left no address: dam construction, displacement and issue salience, Public Administration and Development, 21, 3, 187-200.

[21] Snoubar, Y. (2017). Refugee Girls Children In The Middle East And North Africa: Vulnerabilities And Necessity Of Social Protection. The Journal of International Social Research, 10(50), 809-813.

[22] Snoubar, Y., \& Duman, N. (2016). Impact of Wars and Conflicts on Women and Children in Middle East: Health, Psychological, Educational and Social Crisis. European Journal of Social Sciences Education and Research, 6 (2), 72-76.

[23] Vanderwarker, A. (2012). Water and environmental justice. In Christian-Smith J., And Gleick P.H., With Cooley H., Allen L., Vanderwarker A., And Berry K.A. A Twenty-First Century U.S. Water Policy.

[24] WCD. (2000). Dams and development: a new framework for decisi. The Report of the World Commission on Dams, Earthscan Publications Ltd, London.on-Making.

[25] Wood J.R.. (2007). The politics of water resource development in India :The Narmada Dams Controversy by sage publication.

[26] World Bank.. (2005). Socioeconomic study and proposal for livelihood improvements: badin and thatta districts, sindh, pakistan. Agriculture and Rural Development Sector Unit, South Asia Region. 